\title{
Atonement of harm as an indicator of changes in the legal consciousness of the person who committed a credit fraud
}

\author{
Sona Martirosovna Mkrtchian ${ }^{1}$, Lyubov Valentinovna Lobanova, and Larisa Nikolaevna \\ Larionova \\ Volgograd State University, Department of Criminal Law, Institute of Law, Volgograd, Russia
}

\begin{abstract}
The idea of this study is based on the assumption that the reason for the unjustified application of the criminal law provisions on accounting by law enforcement agencies when punishing various variants of positive post-criminal behaviour, which are varieties of atonement of the harm caused by a crime, is a lack of attention to the nature of atonement as one of the indicators of positive changes in the legal consciousness of a person who has committed a crime, that is, an insufficiently thorough assessment of the characteristics of the personality of the perpetrators, the degree of rooting of antisocial attitudes in their minds, as well as the level of assimilation of legal values and ideals of law-abiding behaviour. The purpose of the study is to identify and study the aspects of the content of the term "atonement of harm" in the meaning provided for in clause " $\mathrm{k}$ " part 1 of Art. 61 of the Criminal Code of the Russian Federation, taking into account the interpretation of the corresponding varieties of positive post-criminal behavior as an indicator of a change in the legal consciousness of a person who has committed a credit fraud. The study is based on the widespread use of the formal legal research method in conjunction with the philological, systemic and logical methods of interpreting regulations. A comprehensive analysis of the content of various types of atonement of the harm caused by a crime as the indicators of positive changes in the legal consciousness of a person who committed credit fraud was carried out for the first time. The results of this study can be used to improve the practice of application of criminal-legal means of accounting for positive post-criminal behavior in the form of atonement when imposing punishment not only on credit fraudsters, but also on persons who have committed other crimes. The author's concept of the criteria that form the content of the varieties of making amends is presented herein.
\end{abstract}

Keywords: crime, punishment, crime prevention, credit, amends

\section{Introduction}

\footnotetext{
${ }^{1}$ Corresponding author: s.mkrtchian1992@volsu.ru
} 
According to the theory of law, the legal consciousness of an individual is the sum of the legal knowledge and ideas that he has mastered and that determine his attitude to law and the legal reality, as well as legal attitudes and orientations, a unique combination of which can lead to the formation of certain attitudes that accumulate the most typical assessments of legal reality determined by the content of his life activity [1]. If such attitudes are negative, then they result in a distortion of the ideological and psychological basis of the individual, which can be expressed, inter alia, in opposing the idea of law to values of a non-legal nature and ultimately lead to the choice of criminal behavior [1]. In this regard, the decision of the Russian legislator to provide for the possibility of a very significant reduction in the amount of liability, subject to the presence of mitigating circumstances, which are a variety of atonement of harm (clause "k" part 1 of Art. 61 and part 1 of Art. 62) seems justifiable, as the performance of appropriate actions by the guilty part helps it to assimilate the ideals and requirements of law-abiding behavior, that is, to change its legal consciousness, to reform it and prevent crimes. These features, in turn, explain the reasons why the presence of other circumstances, the essence of which differs from those described in clause "k" part 1 of Art. 61 of the Criminal Code of the Russian Federation, is unable to entail the application of Part 1 of Art. 62 of the Criminal Code of the Russian Federation.

\section{$2 \quad$ Methods}

The study is based on the widespread use of the formal legal research method in conjunction with the philological, systemic and logical methods of interpreting regulations. The empirical basis of the study includes the results of studying materials from judicial and other law enforcement practice, as well as official statistics.

\section{$3 \quad$ Results}

Table 1. Atonement, kinds and criterions.

\begin{tabular}{|l|l|l|}
\hline $\begin{array}{l}\text { A kind of } \\
\text { atonement of harm }\end{array}$ & Voluntary compensation for damage & $\begin{array}{l}\text { Other actions aimed at atonement of } \\
\text { harm }\end{array}$ \\
\hline $\begin{array}{l}\text { The criterion for the } \\
\text { content of the harm } \\
\text { caused and the } \\
\text { means of its } \\
\text { atonement }\end{array}$ & $\begin{array}{l}\text { 1) property damage or moral } \\
\text { damage; } \\
\text { 2) monetary means are usually the } \\
\text { compensation means }\end{array}$ & $\begin{array}{l}\text { 1) negative consequences that are } \\
\text { neither property damage nor moral } \\
\text { harm; } \\
\text { 2) monetary means are not necessary a } \\
\text { means of compensation; } \\
\text { 3) the nature of compensation depends } \\
\text { on: a) the nature of the criminal offense } \\
\text { committed and the consequences that } \\
\text { have occurred; b) the fact of acceptance } \\
\text { by the victim of the means proposed by } \\
\text { the guilty part to mitigate the negative } \\
\text { consequences }\end{array}$ \\
\hline Volume criterion & $\begin{array}{l}\text { In full or on condition of absolute } \\
\text { proportionality of compensation } \\
\text { (provision of an equivalent) }\end{array}$ & $\begin{array}{l}\text { Partial compensation for harm is also } \\
\text { possible }\end{array}$ \\
\hline Source criterion & $\begin{array}{l}\text { Carried out by the guilty part, on its } \\
\text { own }\end{array}$ & $\begin{array}{l}\text { It is carried out both by the guilty part } \\
\text { and by other persons on the initiative of }\end{array}$ \\
\hline
\end{tabular}




\begin{tabular}{|l|l|l|}
\hline & the guilty party, objectively unable to \\
do it on its own
\end{tabular}

\section{Discussion}

According to the clause " $\mathrm{k}$ " part 1 of Art. 61 of the Criminal Code of the Russian Federation, the term "compensation" is used as part of a single phrase together with the concepts of "property damage" and "moral harm". There is no doubt about the judgment that when determining the type of incentive, the essence of the harm must be considered, the compensation of which is mainly of the state's interest [2]. Consequently, without establishing the fact of compensation for direct property damage to the credit institution, it is impossible to establish the existence of a circumstance of "compensation for property damage and moral harm", which consists in full restoration of the property rights of the victim, otherwise the decision of the legislator to define the above forms of positive post-crime behavior should be recognized as meaningless. Some researchers suggest keeping an indication only of the "voluntary atonement of the harm caused to the victim" in clause "k" part 1 of Art. 61 of the Criminal Code of the Russian Federation [3]. The implementation of such a proposal could lead to a violation of the provisions of Article 2 of the Criminal Code of the Russian Federation and Art. 6 of the Code of Criminal Procedure of the Russian Federation, since the state in all cases should strive to ensure an equivalent replenishment of the benefits lost by the victims without allowing the senseless wasting of the incentive potential of the criminal law.

It is also impossible to agree with the opinion that the possibility of taking into account "voluntary compensation for property damage and moral damage" as a mitigating circumstance subject to partial compensation [4], for the reason that the lexical meaning of the combination of the words "compensate" and "compensation" with the words "harm", "damage" includes a sign of the equivalence of goods being replenished and lost ("to replace something missing or lost" [5]). Obviously, only that harm can be subject to compensation, which 1) in its essence is absolutely compensable or can be replaced by an adequate measurable equivalent, as well as 2) is calculable or is recognized as such in accordance with the existing methods of calculation. In this regard, it should be recognized that the practice of imposing punishment under clause " $k$ " of part 1 of Art. 61 and part 1 of article 62 of the Criminal Code of the Russian Federation, subject to recognition of partial compensation for damage, the payment of the initial installment on a loan, which can hardly be generally recognized as positive post-criminal behavior. 
It seems that the scope of the concept of "compensation for damage from credit fraud" should also include the neutralization of the following negative consequences: 1) lost profit in the form of unpaid interest on the loan, 2) moral damage that may be caused as a result of the use of forged official documents, documents on someone else's name or other someone else's personal data (on the extent of the negative impact of the use of someone else's personal data in the commission of various crimes, see [6], as well as on the expansion of the scale of such influence in connection with the development of technology, see [7-10]). Unfortunately, this is not taken into account in practice. For example, P. committed 2 episodes of credit fraud, using the found passport in the name of G. In the indictment, as a mitigating circumstance, it was indicated "voluntary compensation for property damage caused as a result of the crime to the victim," however, according to the case file, only the amount of the main debt on loans was paid, but no action was taken to mitigate the moral damage caused to G., not to mention its compensation. In such conditions, consideration of the named extenuating circumstance is a mistake.

The position of the researchers who answer affirmatively to the question of the possibility of applying clause "k" part 1 of Art. 61 and part 1 of Art. 62 of the Criminal Code of the Russian Federation in the conditions of compensation to the victim of damage by other persons, and not by the guilty party itself, but on its initiative, if it is not able to do it on its own or at its own expense? Should be supported [11]. However, this is related to another type of redress, provided for by clause "k" part 1 of Art. 61 of the Criminal Code of the Russian Federation - "other actions aimed at atonement of harm inflicted on the victim". The combination of the words "atonement", "harm" or "damage" means mitigation or correction of the consequences resulting from the commission of a crime (see the meaning of the word "atonement": "correction", "mitigation"). This type of atonement of harm may be applicable in cases where a person achieves certain successes in committing significant actions in order to neutralize negative consequences that do not relate to property damage or moral harm or, for reasons beyond his control, cannot be eliminated or replenished through his own material costs.

In this regard, other actions aimed at atonement of harm can also be recognized as partial compensation for harm, since the named type of atonement of harm, provided for by clause " $\mathrm{k}$ " of part 1 of Art. 61 of the Criminal Code of the Russian Federation, does not include the attribute of proportionality of the lost and provided in return benefits. The specified feature of other actions aimed at atonement of harm, predetermines the need to establish the presence in the aggregate of several signs at once: 1) voluntariness; 2) the desire to satisfy the interests of the victim; 3 ) the objective impossibility of realizing the full restoration of the rights of the victim; 4) the consent of the victim to accept the options offered by the guilty to smooth out the consequences of the crime. The law enforcement practice, unfortunately, does not take into account this specificity, which, in particular, took place in the above example. Meanwhile, a public apology can be recognized as one of the possible means of smoothing over the moral harm caused to the owner of personal data that was used in the process of credit fraud, provided that they are accepted by the victim. On the contrary, it is unlikely that an apology can be taken into account in situations of damage caused by fraud to the business reputation of a credit institution and its organizational integrity due to a decrease in the credibility of the organization, loss of trust of stakeholders and a fall in the market value of shares, as well as undermining public morality [12] (on the intermediary function of credit institutions in world practice, the dependence of national economies' indicators on changes in the banking sector and on other circumstances that determine the extraordinary nature of these negative consequences, see [13-16].

\section{Conclusion}


Based on the foregoing, it should be concluded that in all cases when deciding whether there is a fact of the atonement of harm and, therefore, the possibility of applying clause "k" part 1 of Art. 61 and part 1 of Art. 62 of the Criminal Code of the Russian Federation it is required to consider the circumstances indicating 1) the nature of the committed act and the content of its consequences, 2) the characteristics of the guilty party's personality, and 3 ) positive changes in its legal consciousness (readiness to restore the victim's rights to the fullest extent possible, the desire to earn forgiveness and make efforts to take into account interests of the victim, awareness of the stubbornness of criminal behavior in view of the recognition of the value of respecting the rights of others). The results of this study may be useful in improving the practice of applying the provisions of the Criminal Code of the Russian Federation on consideration of positive post-criminal behavior in the form of the atonement of harm when imposing punishment not only on credit fraudsters, but also on persons who have committed other crimes. The study of the chosen topic must be continued, for example, by studying the content and varieties of the atonement of harm as one of the conditions for the implementation of the grounds for exemption from criminal liability and punishment.

\section{References}

1. N.N. Voplenko, Ocherki obshchei teorii prava [Essays on the general theory of law] (VolGU Publishing House, Volgograd, 2009)

2. M.G. Dibirov, Privilegii v ugolovnom prave Rossii [Privileges in the criminal law of Russia]. Abstract of PhD Thesis in Law (Saratov, 2015)

3. I.F. Dedyukhina, Problemy ustanovleniya i realizatsii ugolovnoi otvetstvennosti s uchetom priznakov poterpevshego [Problems of establishing and implementing criminal liability, taking into account the characteristics of the victim], Abstract of $\mathrm{PhD}$ Thesis in Law (Moscow, 2008)

4. V.M. Stepashin, Spetsialnye pravila naznacheniya nakazaniya i inykh mer ugolovno-pravovogo kharaktera [Special rules for imposing punishment and other measures of a criminal law nature] (Jurlitinform, Moscow, 2012)

5. S.I. Ozhegov, Slovar russkogo yazyka [Russian vocabulary], in N.Yu. Shvedova (ed.) (Sovetskaya entsiklopediya, Moscow, 1937)

6. O. Ben-Shahar, J. Legal Analysis 11, 104-159 (2019). https://doi.org/10.1093/jla/laz005

7. C.M.M. Reep-van den Bergh, M. Junger, Crime Sci 7, 5 (2018). https://doi.org/10.1186/s40163-018-0079-3

8. S.G. Correia, Crime Sci 8, 4 (2019). https://doi.org/10.1186/s40163-019-0099-7

9. D.A. Bermudez Villalva, J. Onaolapo, G. Stringhini, et al., Crime Sci 7, 17 (2018). https://doi.org/10.1186/s40163-018-0092-6

10. D.J. Marcus, Duke L.J. 68(3), 555-593 (2018)

11. S.G. Arapidi, Naznachenie nakazaniya pri nalichii smyagchayushchikh obstoyatelstv: zakonodatelnaya reglamentatsiya i problema individualizatsii [Appointment of punishment in the presence of mitigating circumstances: legislative regulation and the problem of individualization], Abstract of PhD Thesis in Law (Moscow, 2005)

12. M. Junger, V. Wang, M. Schlömer, Crime Sci 9, 13 (2020). https://doi.org/10.1186/s40163-020-00119-4

13. R.S. Njotoprajitno, B. Hadianto, Melvin, Banks and Bank Sys., 15(3), 199-206 (2020). https://doi.org/10.21511/bbs.15(3).2020.17 
14. S. Frolov, F. Shukairi, Banks and Bank Sys. 15(3), 184-198 (2020). https://doi.org/10.21511/bbs.15(3).2020.16

15. I.S. Blahun, I.I. Blahun, S.I. Blahun, Banks and Bank Sys. 15(3), 171-183 (2020). https://doi.org/10.21511/bbs.15(3).2020.15

16. O. Butzbach, G. Rotondo, T. Desiato, Accounting, Econ., and Law: A Convivium 10(1) (2020). https://doi.org/10.1515/ael-2017-0004 